\title{
PENGARUH PEMBERIAN VAKSIN WHOLE CELL KILLED VIRUS \\ TERHADAP SINTASAN UDANG VANNAMEI \\ (Lithopenaeus vannamei) YANG DIINFEKSI \\ WHITESPOT BACULOVIRUS (WSBV)
}

\section{THE INFLUENCE OF WHITESPOT BACULOVIRUS (WSBV) INFECTION IN Lithopenaeus vannamei BY GIVING WHOLE CELL KILLED VIRUS VACCINE ON SURVIVAL RATE.}

\author{
Hari Suprapto, Angga Bahtera Siswanto dan Boedi Setya Rahardja \\ Fakultas Perikanan dan Kelautan Universitas Airlangga \\ Kampus C Mulyorejo - Surabaya, 60115 Telp. 031-5911451
}

\begin{abstract}
Shrimp are susceptible to a wide variety of pathogens, one of each were viruses. Whitespot Baculovirus (WSBV) is one of virus attack in vannamei. Shrimp had been infected by WSBV will showed high mortality. One of Strategies for prophylaxis and control of WSBV is enhancement of disease resistant by using vaccines. Recently, quasi-immune response have been reported by which Penaeus japonicus surviving from WSBV infections possess a resistance against challenge WSBV (Venegas et al., 2000). This study was used Lithopenaeus vannamei that been vaccination with inactived-formaline WSBV virus cell or it called Whole Cell Killed Virus (WCKV) to know its responses to WSBV. The aim of this study was to know the effect Whole Cell Killed Virus vaccine to survival rate vannamei shrimp (Lithopenaeus vannamei) infected by Whitespot Baculovirus (WSBV). This study used descriptive study. The efficacy of vaccines made of inactivated WSSV with different dose. The dose are P1 (dose $0,01 \mu \mathrm{g} / \mathrm{ml} \mathrm{each}$ shrimp), P2 (dose 0,02 $\mu \mathrm{g} / \mathrm{ml}$ each shrimp), P3 (dose 0,03 $\mu \mathrm{g} / \mathrm{ml}$ each shrimp) dan P4 (non-vaccine (kontrol) injected by PBS). Primary parameter was survival rate (\%). Secondary parameter was water quality which of temperature, $\mathrm{pH}$, salinity and dissolved oxygen. The result showed that survival rate of L. Vannamei with different dose of WCKV vaccines was increases.
\end{abstract}

Key words : Lithopenaeus vannamei, vacination, WCKV

\section{Pendahuluan}

Udang vannamei memiliki kelebihan diantaranya pertumbuhannya cepat, dapat dibudidayakan dengan kepadatan yang tinggi dan harga pasar cukup tinggi (Nur'aini dkk., 2007). Ekawati (2008) menyatakan berdasarkan data pemerintah kapasitas produksi udang jenis vannamei dalam negeri mencapai 270 ton per tahun. Dalam budidaya sering timbul berbagai kendala yang salah satunya adalah adanya serangan penyakit.

Udang sangat rentan terhadap serangan penyakit yang disebabkan oleh parasit, jamur, protozoa, bakteri dan virus (Astuti, 2009). Sekitar 40\% dari produksi udang hilang akibat infeksi penyakit, terutama penyakit yang disebabkan oleh serangan virus. Salah satu jenis virus yang menyerang udang vannamei yaitu Whitespot Baculovirus (WSBV) atau lebih dikenal dengan nama white spot syndrome (WSS) (Wittevelldt, 2006). Udang yang telah terinfeksi WSBV akan menunjukkan kematian yang tinggi dan rata-rata kematian sampai $100 \%$ dalam jangka waktu 3-10 hari (Liu et al., 2009).

Penanganan penyakit yang disebabkan oleh virus yang menyerang udang belum banyak dilakukan. Strategi pencegahan dan kontrol terhadap serangan WSBV adalah dengan meningkatkan kekebalan tubuh terhadap penyakit, salah satunya dengan menggunakan vaksin (Namikoshi et al., 2003). Udang tidak mempunyai respon imun spesifik dengan immunoglobulin, tetapi akhir-akhir ini dilaporkan adanya quasi-immune response pada Penaeus japonicus. Penelitian yang dilakukan oleh Namikoshi et al. (2003) terdapat proteksi dari infeksi WSBV terhadap Penaeus japonicus yang telah di vaksin dengan WSSV yang telah dimatikan (inactivated WSBV). Pada penelitian ini menggunakan Lithopenaeus vannamei yang di vaksinasi dengan sel virus WSBV yang dimatikan dengan formalin atau disebut Whole Cell Killed Virus (WCKV) untuk mengetahui adanya respon terhadap infeksi WSBV. 


\section{Materi dan Metode Penelitian}

Persiapan udang uji

Udang vannamei (Lithopenaeus vannamei) yang digunakan berumur 2 bulan dengan berat tubuh berkisar antara 20-25 gram sebanyak 80 ekor yang kondisinya sehat dan tidak ada indikasi infeksi penyakit baik secara pengamatan visual maupun keterangan dari tempat asal.

\section{Media pemeliharaan}

Akuarium yang akan digunakan sebanyak 4 buah berukuran 40x 25x $25 \mathrm{~cm}$ yang telah disterilisasi. Menggunakan air payau dengan salinitas 31 ppt dari pengenceran air laut 33 ppt kemudian diencerkan menggunakan rumus pengenceran M1.V1=M2.V2.

\section{Pembuatan Vaksin WCKV}

Pembuatan Vaksin Whole Cell Killed Virus berdasarkan Suprapto dan Rahardja (2003) terdiri dari 3 langkah. Adapun langkah-langkah pembuatannya sebagai berikut:

Pertama sampel udang yang terinfeksi WSBV (White Spot Baculovirus) dikumpulkan berasal dari tambak udang di daerah Jawa Timur. Udang yang terinfeksi virus WSBV dengan berat 10 gram digerus dan ditambahkan PBS hingga cair. Hasilnya dimasukkan ke dalam tabung appendof, kemudian disentrifus dengan kecepatan 1000 rpm selama 10 menit. Hasil sentrifus yang berupa supernatan ditambahkan PEG (Poly Ethylene Glycol) sebanyak $2 \mathrm{ml}$. Kemudian dilakukan sentrifus lagi dengan kecepatan $3800 \mathrm{rpm}$ selama 30 detik. Hasil sentrifus yang berupa endapan dan ditambahkan STE Buffer diforteks sampai kedua bahan menjadi larut. Setelah itu dilakukan sentrifus dengan kecepatan $4000 \mathrm{rpm}$ selama 10 menit. Endapannya dipindah ke tabung sentrifus ultra kemudian disentrifus dengan ultra sentrifus yang berkecepatan 18500 G selama 150 menit. Hasil endapan yang telah disentifus tersebut langsung disimpan pada freezer dengan suhu $-4^{\circ} \mathrm{C}$.

Langkah kedua pembuatan sukrose gradien $50 \%$ dengan cara 1 gram sukrose gradien dalam $2 \mathrm{ml}$ air, pembuatan sukrose gradien $35 \%$ dengan cara 0,7 gram sukrose gradien dalam $2 \mathrm{ml}$ air dan pembuatan sukrose gradien $20 \%$ dengan cara 0,4 gram sukrose gradien dalam $2 \mathrm{ml}$ air.

Langkah ketiga adalah ketiga bahan pada langkah kedua, masing-masing diambil sebanyak $1 \mathrm{ml}$ dan dimasukkan dalam tabung sentrifuse dengan hatihati agar tidak tercampur dan secara berurutan mulai dari dasar tabung sentrifuse yaitu sukrose gradien 50 $\%$, $35 \%, 20 \%$. Kemudian pada bagian paling atas ditambahkan bahan yang sudah dibuat pada langkah 1 dengan diambil endapannya dan ditambahkan STE Buffer diforteks sampai kedua bahan menjadi larut. Selanjutnya dilakukan sentrifuse dengan kecepatan 80.000 G selama 90 menit. Kemudian hasil sentrifuse akan tampak terpisah antara bagian atas, tengah dan bawah tabung sentrifuse, dimana pada bagian atas dan bawah tampak bening sedangkan bagian tengah tampak buram. Bagian tengah yang tampak buram diambil dengan menggunakan jarum suntik dan dipindahkan ke tabung yang berbeda. Hasil yang sudah diambil, kemudian disentrifuse $150.000 \mathrm{G}$ selama 60 menit dengan suhu $4^{\circ} \mathrm{C}$. Hasil sentrifuse tersebut diambil bagian endapannya dan ditambahkan STE buffer. Selanjutnya disentrifus dengan kecepatan 43.000 G selama 30 menit.

\section{Pemberian vaksin WCKV}

Kegiatan yang dilaksanakan pada tahap ini adalah memasukkan udang vannamei yang telah diaklitimatisasi selama satu minggu pada akuarium pemeliharaan sebanyak 10 ekor. Setelah itu dilakukan vaksinasi terhadap udang vannamei. Vaksinasi dilakukan dengan cara suntikan menggunakan spuit 1 ml. Penelitian ini menggunakan 4 perlakuan yaitu vaksinasi dengan Whole Cell Killed Virus dengan dosis $0,01 \mu \mathrm{g} / \mathrm{ml}$ per ekor udang $(\mathrm{P} 1)$, vaksinasi dengan Whole Cell Killed Virus dengan dosis $0,02 \mu \mathrm{g} / \mathrm{ml}$ per ekor udang (P2), vaksinasi dengan Whole Cell Killed Virus dengan dosis $0,03 \mu \mathrm{g} / \mathrm{ml}$ per ekor udang (P3) dan tanpa vaksinasi (kontrol) diinjeksi dengan PBS (P4). Setelah satu minggu pemberian vaksin, dilakukan booster dengan dosis yang sama.

\section{Uji tantang dengan WSBV}

Udang vannamei dipelihara selama 7 hari kemudian diberi perlakuan vaksin Whole Cell Killed Virus. 1 minggu setelah udang vannamei divaksin, dilakukan booster dengan dosis yang sama dengan perlakuan. Kemudian 1 hari setelah dilakukan booster, diuji tantang dengan diinfeksi WSBV melalui intra muscular. Dosis virus yang diberikan adalah LD 50 yang didapat dari penelitian sebelumnya sebesar 0,03 $\mu \mathrm{g} / \mathrm{ml} / \mathrm{ekor}$ udang (Suprapto dan Raharja, 2003). Selanjutnya udang diamati selama 2 minggu setelah uji tantang dan kemudian dilakukan perhitungan jumlah ikan yang masih hidup untuk menghitung sintasan.

\section{Penghitungan Sintasan}

Penghitungan sintasan udang vannamei yaitu persentase jumlah udang vannamei yang masih hidup setelah dilakukan uji tantang. Sintasan dicantumkan 
dalam bentuk persentase (\%) dihitung satu kali pada saat akhir penelitian. Zonneveld et al. (2001) merumuskan sintasan (\%) sebagai berikut:

Sintasan $=\underline{\text { Jumlah udang yang hidup }} \times 100 \%$ Jumlah populasi

Pengamatan data-data kualitas air sebagai data penunjang meliputi suhu dengan menggunakan termometer, $\mathrm{pH}$ dengan menggunakan kertas $\mathrm{pH}$, salinitas dengan menggunakan refraktometer, DO (oksigen terlarut) dengan menggunakan DO test-kit.

\section{Hasil dan Pembahasan}

Berdasarkan pengamatan yang dilakukan selama penelitian tidak terdapat kematian pada Litopenaeus vannamei saat divaksin dengan Whole Cell Killed Virus (WCKV) dan sebelum dilakukan uji tantang dengan Whitespot Baculovirus (WSBV). Hasil Penelitian dapat dilihat pada Gambar 1.

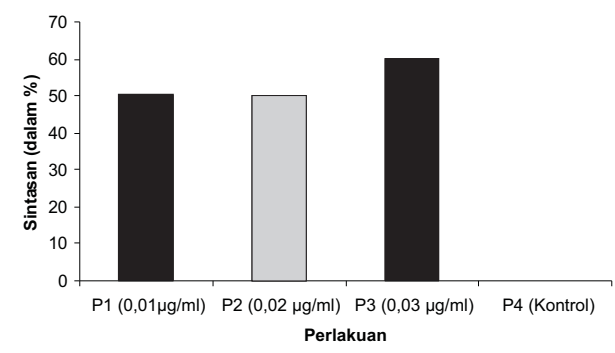

Gambar 1. Pengaruh vaksin Whole Cell Killed Virus terhadap sintasan (dalam \%) udang vannamei (Lithopenaeus vannamei) yang diinfeksi Whitespot Baculovirus (WSBV)

Hasil pengamatan yang dilakukan menunjukkan bahwa awal kematian L. vannamei terjadi pada hari ke 3 dan ke 4 setelah dilakukan uji tantang pada semua perlakuan. Persentase sintasan L. vannamei setelah diuji tantang dengan WSBV menunjukkan bahwa L. vannamei yang divaksin mengalami peningkatan nilai sintasan dibandingkan dengan kontrol. Perlakuan P1 (WCKV 0,01 $\mu \mathrm{g} / \mathrm{ml}$ ) dan perlakuan P2 (WCKV 0,02 $\mu \mathrm{g} / \mathrm{ml}$ ) memiliki nilai sintasan yang sama sebesar $50 \%$. Nilai sintasan pada perlakuan P3 (WCKV 0,03 $\mu \mathrm{g} / \mathrm{ml}$ ) adalah $60 \%$ dan perlakuan $\mathrm{P} 4$ semua hewan uji mati (nilai sintasan $0 \%$ ) Hasil pengamatan kualitas air terlihat bahwa kondisi media pemeliharaan masih dalam kisaran ideal untuk pemeliharaan L. vannamei. Tabel 2 menunjukkan selama penelitian suhu pemeliharaan L. vannamei adalah berkisar antara $28-31^{\circ} \mathrm{C}, \mathrm{pH}$ berkisar antara $7-$ 7,4, salinitas berkisar antara $30-31$ ppt dan oksigen terlarut berkisar antara 5-6 ppm.
Penggunaan Whole cell sebagai vaksin, merupakan salah satu cara yang dapat digunakan untuk mencegah penyakit yang disebabkan oleh infeksi patogen yaitu bakteri dan virus (Nindarwi, 2006). Namikoshi et al. (2003) menyatakan bahwa udang tidak mempunyai respon imun adaptif dengan imunoglobulin, tetapi saat ini respon quasi imun telah dilaporkan tentang udang kuruma (Penaeus japonicus) yang mampu bertahan dari infeksi WSSV karena mempunyai resistensi melawan serangan WSSV.

Berdasarkan hasil penelitian persentase sintasan meningkat menjadi $60 \%$ pada perlakuan $\mathrm{P} 3$. Pada perlakuan P2 dan P3 nilai sintasan sama yaitu $50 \%$. Hal ini diduga bahwa kandungan hemosit pada udang yang telah divaksin dengan WCKV meningkat, sehingga muncul adanya respon pertahanan diri terhadap infeksi virus. Hal ini sesuai dengan penelitian yang dilakukan Namikoshi et al. (2003) bahwa penggunaan WSBV yang di inaktifkan dengan menggunakan formalin dapat meningkatkan kekebalan tubuh udang melawan WSBV. Udang tidak melindungi dari infeksi tetapi melindungi diri terhadap keganasan serangan virus (Johnson et al., 2008).

Johnson et al. (2008) menyatakan, pemberian virus yang diinaktifkan dengan formalin sebagai vaksin diberikan melalui injeksi secara intramuskular atau melalui pakan menunjukkan adanya respon imun udang. Hemosit udang memiliki peranan yang penting pada respon imun meliputi mengenali sel asing, fagositosis, melanisasi, sitotoksis dan komunikasi antar sel. Udang yang sehat memiliki jumlah hemosit yang lebih tinggi dibandingkan dengan udang yang terinfeksi virus (Yeh et al., 2008).

Persentase sintasan yang rendah pada kontrol disebabkan karena rendahnya respon imun pada tubuh L. vannamei. Hal ini menyebabkan kurangnya kemampuan untuk merangsang antibodi dalam tubuh, sehingga saat dilakukan uji tantang dengan White Spot Baculovirus (WSBV) mekanisme pertahanan tubuh $L$. vannamei rendah. Yeh et al. (2008) menyatakan, infeksi WSSV dapat menyebabkan kematian hingga $100 \%$.

Boyd (1989) menyatakan bahwa kandungan oksigen terlarut yang aman bagi kehidupan ikan dan udang adalah lebih dari 5 ppm dan kisaran $\mathrm{pH}$ yang normal antara 7 - 9. Kandungan oksigen terlarut selama penelitian pada tahap aklimatisasi dan tahap vaksinasi L. vannamei adalah 6 ppm. Pada tahap uji tantang kandungan oksigen menurun menjadi 5 ppm, hal ini disebabkan konsumsi oksigen meningkat sehingga menyebabkan kandungan oksigen menurun. Nindarwi (2006) menyatakan bahwa kandungan oksigen yang 
menurun menyebabkan kandungan $\mathrm{CO}_{2}$ meningkat sehingga suasana menjadi lebih asam ( $\mathrm{pH}$ menurun). Berdasarkan hasil pengukuran kandungan oksigen dan $\mathrm{pH}$ air selama penelitian pada tahap uji tantang masih dalam batasan aman untuk pemeliharaan L. vannamei.

\section{Kesimpulan}

Terjadi peningkatan sintasan L. vannamei yang divaksin WCKV (Whole Cell Killed Virus) hingga $50 \%$ dengan dosis $0,01 \mu \mathrm{g} / \mathrm{ml}$ dan $0,02 \mu \mathrm{g} / \mathrm{ml}$ dan mencapai $60 \%$ dengan dosis $0,03 \mu \mathrm{g} / \mathrm{ml}$.

\section{Daftar Pustaka}

Astuti, S. M.2009. Penyakit Parasiter pada Udang.http:/www.tambak.org

Azwar, S. 2004. Metode Penelitian. Pustaka Pelajar. Yogyakarta. 145 hal. Boyd, C. E.1989. Water Quality Management and Aeration in Shrimp Farming. Fisheries and Alied Aquaculture Departemential Series No 2. Alabama Agriculture Experiment Station. Auburn University. USA. 79 hal.

Johnson, K. N., M. C. W. van Hulten and A. C. Barnes. 2008. Vaccination of Shrimps Against Viral Pathogens:Phenomenology and Underlying Mechanism. Vaccine 26:4885-4892.

Liu, H., K. Soderhall and P. Jiravanichpaisal. 2009. Antiviral Immunity in Crustaceans. Journal Fish and Shellfish Immunology xxx (2009) $1-10$.

Namikoshi A., J. L. Wu, T. Yamashita, T. Nishizawa, T. Nishioka, M. Arimoto and K. Muroga. 2003. Vaccinations Trials With Penaeus japonicus to Induce Resistance to White Spot Sindrome Virus. Aquaculture 229 (2004) 25-35.
Nindarwi, D. N. 2006. Studi Perbandingan Penggunaan Whole Cell dan Extraceluller Product dari Vibrio alginolyticus sebagai Vaksin secara Oral Terhadap Sintasan Benih Ikan Kerapu Macan (Epinephelus fuscogutatus).Skripsi.Fakultas Perikanan d a n K lautan Universitas Airlangga.Surabaya 56 hal.

Nur'aini, Y. L., H. Bambang, S. Subyakto, dan T. Gemi. 2007. Active Surveilance of Infectious Myonecrosis Virus (IMNV) in PondCultured White Shrimp (Lithopenaeus vannamei) in East Java and Bali. Jurnal Perikanan UGM. IX (1) : 25-31.

Witteveldt, J. 2006. On the Vaccination of Shrimp Against White Spot Syndrome Virus. Thesis Wageningen University.129pp.

Yeh, S., Y. Chen, S. Hsieh, W. Cheng and C. Liu. 2008. mmune Response of White Shrimps, it. Litopenaeus vannamei, After A Concurrent Infection With White Spot Syndrome Virus and Infectious Hypodermal and Hematopoietic Necrosis Virus. Fish and Shellfish Immunology, 26 (2009):582-588.

Zonneveld, N., E. A. Huisman and J. H. Boon. 2001. Prinsip-prinsip Budidaya Ikan. Gramedia Pustaka Utama. Jakarta. 317 hal. 